\title{
Cholinesterase in different types of the muscle tissue during the early postmortem period for diagnosis of death coming
}

Lidiya Cherkashyna ${ }^{1}$, Anton Shklyar ${ }^{2}$, Roman Sukhonosov ${ }^{3}$, Olha Miroshnikova ${ }^{4}$ Ludmyla Naguta ${ }^{5}$, Vasyl Olkhovskiy, Nadiia Demikhova ${ }^{7}$, Larysa Kuts ${ }^{8}$, Ganna Barchan ${ }^{9}$, Ganna Sukhomlyn ${ }^{10}$, Ludmila Kyptenko ${ }^{11}$

\begin{abstract}
Summary
The purpose of the research: consisted in study of postmortem regularities in the content of cholinesterase in different types of muscle tissue (MT) for improving accuracy of determination of the prescription of death coming PDC.Materials and methods: The activity/level of cholinesterase was determined in homogenates of the myocardial $(\mathrm{MMH})$, oesophageal $(\mathrm{OMH})$, diaphragm $(\mathrm{DMH})$ and intercostal muscles (IMH)within the early PMP (3-13 hours after the coming of death) on 30 human corpses. MT was sampled in conditions of postmortem biopsy with use of special instruments; MT homogenates were prepared following the standard technique with subsequent determination of cholinesterase content in MT homogenates. Results and discussion: The analysis of postmortem changes in the content of cholinesterase in MT depending upon PDC revealed that after 3 hours from the moment of death coming its highest content was in muscles of the oesophagus, the least one being in MT of the intercostal muscles (respectively, (2,717.1 \pm 37.1$)$ and $(883.5 \pm 6.2) \mathrm{U} / \mathrm{g}, \mathrm{p}<0.001)$. Levels of cholinesterase content in MT of the myocardium and diaphragm were rather close, though they differed (respectively, $(1,213.8 \pm 8.8)$ and $(1,512.8 \pm 11.5) \mathrm{U} / \mathrm{g}, \mathrm{p}<0.05)$, and occupied an intermediate place between the corresponding values of MT of the intercostal muscles and oesophagus.A common pattern for the content of cholinesterase in different types of MT was characterized by a decrease of this content with an increase in PDC terms; besides, the dynamic lines of its changes, that we obtained, became basic ones for substantiating quantitative time dependencies and construction of relevant nomograms for forensic diagnosis of PDC by cholinesterase content in MT. Conclusions: It was proved that the content of cholinesterase in all MT homogenates, which we studied, changed regularly (and nonlinearly), but the initial and final levels of cholinesterase content differed depending upon the type of MT. Besides, the dynamics in changes of the content of cholinesterase within the time period of $3 \div 13$ hours from the moment of death coming differed upon the type of MT too. Advantages of the technique consist in theintegrity of biochemical examination of different types of MT and simplicity in interpretation of findings. The application of the nomogram technique for assessing PDC by cholinesterase content in MT makes it possible to improve the accuracy of diagnosis for terms of the coming of death up to 60 minutes.
\end{abstract}

Keywords: early postmortem period;prescription of death coming;muscle tissue; cholinesterase.

Bangladesh Journal of Medical Science Vol. 20 No. 01 January’21. Page : 95-100 DOI: https://doi.org/10.3329/bjms.v20i1.50352

\section{Introduction:}

Determination of the postmortem interval is an obligatory and important stage in forensic examination
(FE) of corpses ${ }^{1-4}$. This parameter is one of the basic markers for an objective and complete carrying out of expert examination, its absence casting doubt on the

1. Lidiya Cherkashyna, Associate Professor of the Department Family Medicine, Folk and Alternative Medicine, Kharkiv Medical Academy of Postgraduate Education, Kharkiv, Ukraine; serg_shklyar@ukr.net; Orcid ID 0000-0002-6414-8077

2. Anton Shklyar, Associated Professor, Department of Human Anatomy, Kharkiv National Medical University, Kharkiv, Ukraine; serg_shklyar@ukr.net

3. Roman Sukhonosov, lecturer of the Department of Human Anatomy, Kharkiv National Medical University, Kharkiv, Ukraine; r.sukhonosov@ukr.net

4. Olha Miroshnikova, Associated Professor, State Zooveterinary Academy, Kharkiv, Ukraine; 1.miroshnikova@ukr.net

5. Lyudmyla Naguta, Associated Professor, Kharkiv National Medical University, Kharkiv, Ukraine; 1.naguta@ukr.net

6. Vasyl Olkhovskiy, Prof., Department of Forensic Medicine and Medical Law, Kharkiv National Medical University, Kharkiv, Ukraine; vasyl.olkhovskiy@ukr.net

7. Nadiia Demikhova, Professor, Department of Family Medicine, Sumy State University, Sumy, Ukraine; n.demyhova@med.sumdu.edu.ua

8. Larysa Kuts, Professor, Department of Family Medicine, Sumy State University, Sumy, Ukraine; larisa.kuts@fmail.ua. Orcid ID https://orcid.org/0000-0002-4156-31639.

9. Ganna Barchan, assistant professor of department of pediatrics, Kharkiv National Medical University, Kharkiv, Ukraine; annabarchan@gmail.com

10. Ganna Sukhomlyn, Associate Professor of the Department of of clinical disciplines, Donetsk National Medical University, Kropyvnytskyi, Ukraine; g.sukhomlyn@gmail.com

11. Ludmila Kyptenko, Associated Professor, Department of Morphology, Sumy State University, Sumy, Ukraine; 1.kiptenko@med.sumdu.edu.ua

Correspondence to: Nadiia Demikhova, Professor, Department of Family Medicine, Sumy State University, Sumy, Ukraine; n.demyhova@med.sumdu.edu.ua 
legal significance of FE as criminal (civil) evidence. The paramount scientific importance of studying the postmortem interval consists in the presence of this problem in the basic areas of scientific researches, which are determined by the effective Scientific Speciality Code "14.01.25 - Forensic Medicine" in Ukraine. Item 2.5 of the basic areas of scientific researches in the above Code has exactly this formulation: "Determination of the prescription of death coming" ${ }^{-8}$. Besides, according to Regulations on the Office of the Chief Medical Examiner in health administrations of regional executive committees and the Republican Office (the Autonomous Republic of Crimea), approved by Order of the Ministry of Health of Ukraine "On the development and improvement of the forensic service in Ukraine" No. 6, dated January 17, 1995, sub-item 2.6 of item 2 "Tasks of the Office" demands to improve the quality of expert examinations by application of new research methods to forensic practice in order to advance the activity of medical examiners. It is for this reason that an interest in studying informative criteria in the context of determination of the prescription of death coming (PDC) is natural ${ }^{6,9-12}$. On the other hand, the activity/level of cholinesterase in the muscle tissue (MT) from positions of forensic investigation for PDC during the early postmortem period (PMP) was not studied before.

The purpose of the research consisted in study of postmortem regularities in the content of cholinesterase in different types of MT for improving accuracy of determination of PDC.

Materials and methods:The activity/level of cholinesterase was determined in homogenates of the myocardial (MMH), oesophageal (OMH), diaphragm (DMH) and intercostal muscles (IMH) within the early PMP (3-13 hours after the coming of death) on 30 human corpses. MT was sampled in conditions of postmortem biopsy with use of special instruments; MT homogenates were prepared following the standard technique 2,3,13 with subsequent determination of cholinesterase content in MT homogenates by the kinetic method using butyrylthiocholine with help of the commercial test system of SpineLab Ltd. company (Ukraine) on a Labline-80 biochemical analyzer (Austria) in accordance with their instructions. The findings were also analysed statistically with help of variation statistics and assessment of the normality of distribution and reliability of findings 14-29. Information analysis of the pathometric sign (cholinesterase content) was made by calculation of its comparative informativeness (I, bit) during each time interval as $\mathbf{I}=-\mathbf{p} \times \log _{2} \mathbf{p}$, where $\mathbf{p}$ is the relation between the content of cholinesterase after 3 hours and its content in the relevant postmortem time interval ${ }^{1,2,30}$. Presentation of revealed regularities in changes of cholinesterase content in each type of MT homogenates is provided by building dynamic lines with polynomials of different (2-5) stages and accuracy of reproduction $\mathrm{R}^{2}>0.95^{14,31}$. The tabular nomogram was devised by dynamic extrapolation of polynomial dependencies with an interval of 30 minutes. The studies were conducted following the basic regulations of Ethical Principles for Medical Research Involving Human Subjects approved by the Declaration of Helsinki (1964-2013), ICH GCP (1996), EEU Directive No. 609 (dated November 24, 1986), Orders of the Ministry of Health of Ukraine No. 690 (dated September 23, 2009), 944 (dated December 14, 2009) and 616 (dated August 03, 2012).

Ethical clearance: (no need for review article) This research proposal was accepted by the Ethics Committee of Kharkiv Medical Academy of Postgraduate Education, Ukraine

Results and discussion: The analysis of postmortem changes in the content of cholinesterase in MT depending upon PDC revealed that after 3 hours from the moment of death coming its highest content was in muscles of the oesophagus, the least one being in MT of the intercostal muscles (respectively, $(2,717.1 \pm 37.1)$ and $(883.5 \pm 6.2) \mathrm{U} / \mathrm{g}, \mathrm{p}<0.001$; Table 1).

Levels of cholinesterase content in MT of the myocardium and diaphragm were rather close, though they differed (respectively, (1,213.8 \pm 8.8 ) and $(1,512.8 \pm 11.5) \mathrm{U} / \mathrm{g}, \mathrm{p}<0.05)$, and occupied an intermediate place between the corresponding values of MT of the intercostal muscles and oesophagus (Fig. 1).

A common pattern for the content of cholinesterase in different types of MT was characterized by a decrease of this content with an increase in PDC terms; besides, the dynamic lines of its changes, that we obtained (See Table 1), became basic ones for substantiating quantitative time dependencies and construction of relevant nomograms for forensic diagnosis of PDC by cholinesterase content in MT.

The quantitative dependencies between the content of cholinesterase and PDC, that we statistically justified, have the analytical form (polynomial 
Table 1. Levels of the content (U/g), quantitative-analytical regularities ( $\mathrm{Y}$ ) in changes and diagnostic significance (I, bits) of the content of cholinesterase in different morphological types of the muscle tissue during the early postmortem period depending upon the prescription of death coming.

\begin{tabular}{|c|c|c|c|c|c|c|}
\hline \multirow{2}{*}{$\begin{array}{c}\text { Content }\left(\mathrm{Y}_{6}\right) \\
\text { of cholinesterase and } \\
\text { itsinformativeness }\end{array}$} & \multicolumn{6}{|c|}{ Postmortem time intervals (hours) } \\
\hline & 3 & 5 & 7 & 9 & 11 & 13 \\
\hline \multirow{4}{*}{$\begin{array}{l}\text { In homogenates of the myocardial } \\
\text { muscles, } \mathrm{MMH}, \mathrm{U} / \mathrm{g} \\
\mathrm{I}_{\mathrm{M}-6}=1.782 \mathrm{bits}\end{array}$} & 1213.8 & 766.3 & 947.2 & 862.0 & 848.5 & 834.4 \\
\hline & $\pm 8.8^{\mathrm{a}}$ & $\pm 79.8^{\mathrm{a}}$ & $\pm 7.0^{\mathrm{a}}$ & $\pm 5.8^{\mathrm{a}}$ & $\pm 5.7^{\mathrm{a}}$ & $\pm 5.4^{\mathrm{a}}$ \\
\hline & 0.000 & 0.419 & 0.279 & 0.351 & 0.361 & 0.372 \\
\hline & \multicolumn{6}{|c|}{$Y_{M-6}=-13.68 x^{5}+256.6 x^{4}-1825 x^{3}+6084 x^{2}-9346 x+6058 ; R^{2}=1.0$} \\
\hline \multirow{4}{*}{$\begin{array}{l}\text { In homogenates of the intercostal } \\
\text { muscles, } \mathrm{IMH}, \mathrm{U} / \mathrm{g} \\
\mathrm{I}_{\mathrm{R}-6}=1.607 \mathrm{bits}\end{array}$} & 883.5 & 790.4 & 707.6 & 645.9 & 544.9 & 525.3 \\
\hline & \pm 6.2 & $\pm 7.3^{\mathrm{a}}$ & $\pm 10.2^{\mathrm{a}}$ & \pm 5.4 & \pm 5.1 & \pm 5.3 \\
\hline & 0.000 & 0.144 & 0.256 & 0.330 & 0.430 & 0.446 \\
\hline & \multicolumn{6}{|c|}{$Y_{R-6}=5.252 x^{2}-110.7 x+990.8 ; R^{2}=0.99$} \\
\hline \multirow{4}{*}{$\begin{array}{l}\text { In homogenates of the diaphragm } \\
\text { muscles, DMH, U/g } \\
\mathrm{I}_{\mathrm{D}-6}=1.364 \mathrm{bits}\end{array}$} & 1512.8 & 1446.4 & 1285.0 & 1224.1 & 973.9 & 900.8 \\
\hline & \pm 11.5 & \pm 11.1 & \pm 10.0 & \pm 9.9 & \pm 7.7 & \pm 5.8 \\
\hline & 0.000 & 0.062 & 0.200 & 0.247 & 0.409 & 0.445 \\
\hline & \multicolumn{6}{|c|}{$Y_{D-6}=3.559 x^{4}-45.29 x^{3}+182.8 x^{2}-378.4 x+1754 ; R^{2}=0.983$} \\
\hline \multirow{4}{*}{$\begin{array}{l}\text { In homogenates of the oesophageal } \\
\text { muscles, } \mathrm{OMH}, \mathrm{U} / \mathrm{g} \\
\mathrm{I}_{\mathrm{O}-6}=0.914 \text { bits }\end{array}$} & 2717.1 & 2497.4 & 2127.6 & 1840.6 & 1429.1 & 1281.4 \\
\hline & \pm 37.1 & $\pm 21.4^{\mathrm{a}}$ & $\pm 20.4^{\mathrm{a}}$ & \pm 17.2 & \pm 15.9 & \pm 10.1 \\
\hline & 0.000 & 0.112 & 0.197 & 0.181 & 0.283 & 0.141 \\
\hline & \multicolumn{6}{|c|}{$\mathrm{Y}_{\mathrm{O}-6}=3.447 \mathrm{x}^{2}-329 \mathrm{x}+3081 ; \mathrm{R}^{2}=0.98$} \\
\hline
\end{tabular}

Note: ${ }^{a}-$ reliable differences from the previous interval at the level of $p<0.05$.

stages 2-5) and their use enabled us to represent the revealed regularity and determine "intermediate" (between time intervals, with an accuracy of at least $\mathrm{p}<0.01$ ) values of cholinesterase content, thereby in its turn making it possible to increase the accuracy in diagnosing PDC.

Besides, using methods of clinical informatics, we calculated informational values for dynamic changes in the content of cholinesterase for each time period and each type of MT. In particular (See Table 1), it was revealed that the total informativeness of determination of cholinesterase for diagnosing PDC by MT of the myocardium was $\mathrm{I}_{\mathrm{M}-6}=1.782$ bits, by MT of the intercostal muscles $\mathrm{I}_{\mathrm{R}-6}=1.706$ bits, by MT of the diaphragm $\mathrm{I}_{\mathrm{D}-6}=1.364$ bits, by MT of the oesophagusI $_{\mathrm{O}-6}=0.914$ bits. It should be noted that the diagnostic value of determination of cholinesterase content depends upon the type of MT and the term of PDC (time interval of PMP).

Thus, within the time interval from 5 to 11 hours the most informative one was the content of cholinesterase in MT of the myocardium ( $\mathrm{I}=0.419$ 0.279 bits), while during the time interval after 11 hours its content in MT of the intercostal muscles was of a high diagnostic value too ( $\mathrm{I}=0.430 \div 0.446$ bits $)$. Proceeding from the above, the choice of the criterion "cholinesterase content in MT of the myocardium" in PDC before 11 hours is more reasonable and preferred (a higher diagnostic value), but in concrete tasks of FE one can use the criterion "cholinesterase content in MT of the intercostal muscles". In order to apply to practice of FE the regularities, revealed by us in the process of this investigation, and to introduce them into the work of medical examiners we constructed a graphic nomogram and made its simplified (traditional), tabular form (Fig. 1) for determining PDC by the level of cholinesterase in different types of MT.

The presented nomograms make it possible to determine PDC by both a single diagnostic criterion and several ones; in order to provide accuracy at the level of $p<0.05$ it is enough to use one criterion (for example, "cholinesterase content in MT of the myocardium"), but for improving the accuracy (and in conditions of presence of morphological material) it is necessary to use several criteria, and first of all the criterion "cholinesterase content in MT of the intercostal muscles".

An example of forensic determination of PDC by the value of cholinesterase content in different types of MT. In natural conditions of examination of a corpse the following morphological material 
Cholinesterase in different types of the muscle tissue during the early postmortem period for diagnosis of death coming

\begin{tabular}{|c|c|c|c|c|c|c|c|c|c|}
\hline \multicolumn{2}{|c|}{ Prescription of coming } & \multicolumn{8}{|c|}{ Cholinesterase contentin homogenate of muscles $(Y, U / g)$} \\
\hline \multirow{2}{*}{$\begin{array}{c}\text { Minutes } \\
1\end{array}$} & \multirow{2}{*}{$\begin{array}{c}\text { Hours } \\
2\end{array}$} & \multicolumn{2}{|c|}{ Myocardium, $\mathbf{Y}_{\mathrm{M}}$} & \multicolumn{2}{|c|}{ Oesophagus, $Y_{0}$} & \multicolumn{2}{|c|}{ Diaphragm, $\mathbf{Y}_{\mathrm{D}}$} & \multicolumn{2}{|c|}{ Intercostal, $\mathbf{Y}_{\mathrm{R}}$} \\
\hline & & 3 & \multirow{22}{*}{ 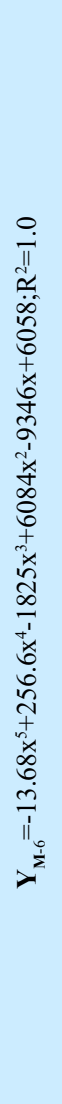 } & 4 & \multirow{22}{*}{  } & 5 & \multirow{22}{*}{ 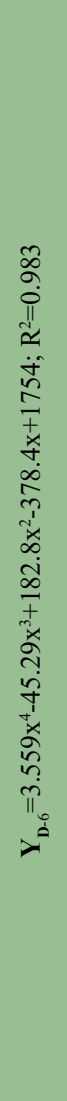 } & 6 & \multirow{22}{*}{ 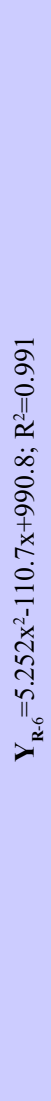 } \\
\hline 180 & 3 hours & 901.1 & & 2675.4 & & 1486.6 & & 860.6 & \\
\hline 210 & $3 \mathrm{~h} 30 \mathrm{~min}$. & 762.3 & & 2595.6 & & 1462.1 & & 836.6 & \\
\hline 240 & 4 hours & 733.9 & & 2516.1 & & 1440.6 & & 813.2 & \\
\hline 270 & $4 \mathrm{~h} 30 \mathrm{~min}$. & 766.8 & & 2437.1 & & 1420.0 & & 790.4 & \\
\hline 300 & 5 hours & 825.3 & & 2358.5 & & 1398.4 & & 768.3 & \\
\hline 330 & 5 h 30 min. & & & 2280.3 & & 1374.3 & & 746.9 & \\
\hline 360 & 6 hours & & & 2202.6 & & 1346.2 & & 726.1 & \\
\hline 390 & $6 \mathrm{~h} 30 \mathrm{~min}$. & & & 2125.3 & & 1313.4 & & 706.0 & \\
\hline 420 & 7 hours & & & 2048.5 & & 1275.3 & & 686.5 & \\
\hline 450 & $7 \mathrm{~h} 30 \mathrm{~min}$. & & & 1972.0 & & 1231.4 & & 667.7 & \\
\hline 480 & 8 hours & & & 1896.0 & & 1181.7 & & 649.5 & \\
\hline 510 & $8 \mathrm{~h} 30 \mathrm{~min}$. & & & 1820.5 & & 1126.7 & & 632.0 & \\
\hline 540 & 9 hours & & & 1745.3 & & 1067.0 & & 615.2 & \\
\hline 570 & 9 h 30 min. & & & 1670.6 & & 1003.4 & & 599.0 & \\
\hline 600 & 10 hours & & & 1596.3 & & 937.4 & & 583.5 & \\
\hline 630 & $10 \mathrm{~h} 30 \mathrm{~min}$. & & & 1522.5 & & 870.3 & & 568.6 & \\
\hline 660 & 11 hours & & & 1449.1 & & 804.2 & & 554.4 & \\
\hline 690 & $11 \mathrm{~h} 30$ min. & & & 1376.1 & & 741.3 & & 540.8 & \\
\hline 720 & 12 hours & & & 1303.5 & & 684.0 & & 527.9 & \\
\hline 750 & $12 \mathrm{~h} 30 \mathrm{~min}$. & & & 1231.4 & & 635.2 & & 515.7 & \\
\hline 780 & 13 hours & & & & & & & & \\
\hline
\end{tabular}

Fig. 1. The quantitative nomogram for determining the term of PDC depending upon the content of cholinesterase in different morphological types of the human muscle tissue with different localizations.

(in the amount of $100 \mathrm{mg}$ ) was isolated by means of postmortem biopsy: MT of the myocardium, MT of the oesophagus, MT of the diaphragm, MT of the intercostal muscles. In conditions of biochemical laboratory the above MT fragments $(100 \mathrm{mg})$ were homogenized in a saline solution at the ratio of $20: 1\left(100 \mathrm{mg}\right.$ in $\left.2.0 \mathrm{~cm}^{3}\right)$. After that the samples were centrifuged during 10 minutes at a speed of 3,000 rpm; $2 \mu \mathrm{l}$ of the supernatant fluid were added to $280 \mu \mathrm{l}$ of the working reagent. After their mixing (30 seconds) at a room temperature $\left(\mathrm{T}=18.0-21.0^{\circ} \mathrm{C}\right)$ we measured absorbance using a CF-46 spectrophotometer at a wavelength of $450 \mathrm{~nm}$; then during 2.0 minutes we measured absorbance repeatedly every 30 seconds. Activity of the enzyme was calculated as cholinesterase $=\mathbf{A} \times \mathbf{1 0} \times \mathbf{1 1 , 3 5 5 . 0}(\mathrm{U} / \mathrm{g})$, where $\mathbf{A}$ is the average change of absorbance (4 measurements), $\mathbf{1 0}$ is the factor for recalculation per $1.0 \mathrm{~g}$ of MT, 11,355 is the factor for recalculation to $\mathrm{U} / \mathrm{g}$. The following values of cholinesterasecontent were obtained: $\mathrm{MMH}_{\mathrm{C}}=$ $798.7 \mathrm{U} / \mathrm{g}, \mathrm{OMH}_{\mathrm{C}}=2,293.5 \mathrm{U} / \mathrm{g}, \mathrm{DMH}_{\mathrm{C}}=1,410.8$
$\mathrm{U} / \mathrm{g}, \mathrm{IMH}_{\mathrm{C}}=752.9 \mathrm{U} / \mathrm{g}$. Proceeding from results of biochemical determination of cholinesteraseactivity in MT homogenates and using the nomogram (See Fig. 1), one can conclude that the term of PDC varies and corresponds to the following terms (See the tabular nomogram): 1) by cholinesterasecontent in MT of the myocardium - from 4 hours 30 minutes to 5 hours, 2) by cholinesterasecontent in MT of the oesophagus - from 5 hours to 5 hours 30 minutes, 3) by cholinesterasecontent in MT of the diaphragm - from 4 hours 30 minutes to 5 hours, 4) by cholinesterasecontent in MT of the intercostal muscles - from 5 hours to 5 hours 30 minutes.

Hence, by data of biochemical examination of the content of cholinesterasein different types of MT, PDC ranged from 4 hours 30 minutes to 5 hours 30 minutes from the moment of sampling of biopsy material. It should be noted that extrinsic factors (factors of the environment, where a corpse is after death), which can affect the dynamics of changes in the content of cholinesterasein different types of MT, were not taken into account; the studies were 
conducted in usual conditions for preservation of corpses.

Using morphological data from 30 corpses and PDC, which was verified in them before, we carried out inverse approbation of the nomogram technique for determination of PDC and revealed that the accuracy of determination for the term of PDC ranged within $\pm(0.5 \div 1.0)$ hours, with diagnostic inaccuracies of the first $(\alpha)$ andsecond $(\beta)$ type at the level of below $10.0 \%$.

Conclusions: It was proved that the content of cholinesterase in all MT homogenates, which we studied, changed regularly (and nonlinearly), but the initial and final levels of cholinesterase content differed depending upon the type of MT. Besides, the dynamics in changes of the content of cholinesterase within the time period of $3 \div 13$ hours from the moment of death coming differed upon the type of MT too. The quantitative analytical and graphical dependences of the change in the content of cholinesterase in MT within the early PMP, revealed during the research, made it possible to substantiate relevant nomograms. Limitations for using the nomogram technique are as follows: PDC more than 6 hours, unknown conditions of the stay of a corpse after the coming of death (influence of environmental factors). Advantages of the technique consist in theintegrity of biochemical examination of different types of MT and simplicity in interpretation of findings. The application of the nomogram technique for assessing PDC by cholinesterase content in MT makes it possible to improve the accuracy of diagnosis for terms of the coming of death up to 60 minutes.

Prospects of further researches regarding improvement in the accuracy of diagnosis of PDC are related to study of in formativeness of other structural-biochemical markers of MT.

Source of Funding: Kharkiv Medical Academy of Postgraduate Education

Conflict of interest: None declared

\section{Authors's contribution:}

Data gathering and idea owner of this study:

Cherkashyna L., Shklyar A.

Study design: Olkhovskliy V., Cherkashyna L., Demikhova N., Barchan G.

Data gathering: Sukhomlyn G., Miroshnikova L., Naguta L., Cherkashyna L.

Writing and submitting manuscript: Cherkashyna L., Shklyar A., Sukhomlyn G., Kuts L., Sukhonosov R., Barchan G.

Editing and approval of final draft: Cherkashyna L., Shklyar A., Demikhova N.

\section{References:}

1. Konoval, N.S. Analysis of archival forensic examinations for determining the limitation period of death. Forensic examination, 2018;2: 32-35.

2. Konoval, N.S. The variability of the criterion of the study of the limitation of the onset of death in the early period. Ukrainian Journal of Medicine, Biology and Sport, 2018;3 (5 / 14): 231-236.

3. Olkhovsky, V.O., Golubovich, L.L., Khizhnyak, V.V. Determining the duration of the post-mortem period in forensic expert practice: current state and prospects. ExpClinMed.2016;4(73): 154-162.

4. Nurunnabi, A., Alim, A., Sabiha, M., Manowara, B., Monira, K., \& Shamim, A. Weight of the Human Thyroid Gland - A Postmortem Study. Bangladesh Journal of Medical Science, 2010:9(1), 44-48. https:// doi.org/10.3329/bjms.v9i1.5230

5. Bachinsky, V.T. Advanced diagnostic capabilities of the previous prescription of death (problems and prospects). Materials of scientific conference "Achievement in the galuse of marine medicine and problem nutrition during medical and medical examinations at the forensic examination and at the forensic examination of corpses", Lviv,2016;302-304.

6. Olkhovsky, V.O., Golubovich, L.L. Determining the prescription of an onset of death. Kharkiv: Brovin OV, 2017; 168p.

7. Cherkashyna, L., Konoval, N., Shklyar, A. et al. Study of structural and biochemical changes in the muscular tissue of the oesophagus for solving the problem of diagnosing the prescription of death coming. Pol Merkur Lekarski, 2020;48(283): 42-44.

8. Cherkashyna, L., Konoval, N., Shklyar, A. et al. The dynamics of changes in biochemical markers of the state of tissue in intercostal muscles during the early postmortem period. Pol Merkur Lekarski,2020:48 (283): 45-48.

9. Garazdyuk, M.S., Bachynsky, V.T., Vanchulyak, O.Y. et al. Determining the prescription of death by twodimensional mapping of polarization-heterogeneous images of polycrystalline liquor films. Clin Exp Pathol, 15 2016;(1): 36-42.

10. Gladkikh, D.B. Forensic diagnostics of the prescription of the onset of death by the supravital reaction of the pupils.Abstractof the PhD dissertation, Kyiv, 2016;19p. 
Cholinesterase in different types of the muscle tissue during the early postmortem period for diagnosis of death coming

11. Gurov, O.M., Kozachenko, I.M., Kutsenko, S.V. et al. Determining the prescription of the onset of death in the early post-mortem period by the supravital reaction of the pupils to the action of pilocarpine.Criminal Foren Med.: An Interagency Scientific and Methodological Collection, 2014;59: 443-451.

12. Kuzovkov, A.V., Vavilov, A.Y.: Objectification of diagnostic algorithms for establishing the limitation of human death by the dynamics of tympanic temperature. Modern ProblSci Edu,2017;2: 12-20.

13. Tewari, S., Gupta, C., Palimar, V., \& Kathur, S. Morphometric analysis of infraorbital foramen in South Indian dry skulls. Bangladesh Journal of Medical Science, 2018;17(4), 562-566.https://doi.org/10.3329/ bjms.v17i4.38316

14. Smiyan, O.I., Manko, Y.A., Loboda, A.M. et al. Influence of magnesium on the state of the cardiovascular system in children with chronic tonsillitis. Wiadomosci lekarskie, 2020; 73(5): 904-908.

15. Jamal, M., Ito, A., Tanaka, N., Takakura, A., Ameno, K., $\&$ Kinoshita, H. The influx of Yaba continues to ravage the Bangladeshi population- a short summary. Bangladesh Journal of Medical Science, 2018;17(3), 518. https://doi. org/10.3329/bjms.v17i3.37013

16. Jamal, M., Ito, A., Tanaka, N., Ameno, K., Miki, T., \& Kinoshita, H. Moderate to high ethanol and acetaldehyde administration decreases c-fos protein expression in the hippocampus of Aldh2-knockout and C57BL/6N mice. Bangladesh Journal of Medical Science, 2019;19(1), 83-89. https://doi.org/10.3329/ bjms.v19i1.43876

17. Kinoshita, H., Tanaka, N., Ohi, T., Jamal, M., Ohkubo, E., \& Ameno, K. Prior surgical intervention of the bone; useful finding for the examination of the skeletal remains. Bangladesh Journal of Medical Science, 2010;9(2), 101-102. https://doi.org/10.3329/ bjms.v9i2.5658

18. Barchan, G., Demikhov, O., Cherkashyna, L. et al. A complex of regional ecological and medico-social factors: evaluation of dysplastic dependent pathology of the bronchopulmonary system.Pol Merkur Lekarski,2020;48 (283): 49-54.

19. Yarmolenko, O., Sikora, V., Bumeister, V. et al. Agedependent cardioprotective action of meldonium on heart remodeling under the experimental hypoosmolar hyperhydration Bangladesh J Med Sci, 2019;18 (2):395401.https://doi.org/10.3329/bjms.v18i2.40714

20. Marushchak, M., Krynytska, I., Petrenko N., et al. The determination of correlation linkages between level of reactive oxygen species, contents of neutrophils and blood gas composition in experimental acute lung injury. Georgian Medical News, 2016;4(253), 98-103.

21. Stepanova, N., Korol, L., Burdeyna, O. Oxidative stress in peritoneal dialysis patients: Association with the dialysis adequacy and technique survival. Indian
Journal of Nephrology,2019;29(5), 309-316. https://doi. org/10.4103/ijn.IJN 242 18

22. Korol, L., Mygal, L., Stepanova, N. Intensity of oxidative stress and activity of angiotensin converting enzyme in blood of patients with uncomplicated pyelonephritis. The Ukrainian Biochemical Journal,2017;89(2): 99-105.

23. Prykhodko, O., Gulaya, V., Yarmolenko, O. et al. Microscopic changes in the organs of rats under conditions of general dehydration of the organism. Azerbaijan Medical Journal, 2016;4: 95-100.

24. Marushchak, M., Maksiv, K., Krynytska, I. The specific features of free radical oxidation in patients with chronic obstructive pulmonary disease and arterial hypertension. Pol MerkurLekarski,2019;47(279): 95-98.

25. Demikhova, N., Smiianov, V., Prikhodko, O. et al. Information and telecommunication technologies and problem-based learning in the formation of competitive competence in medical masters of Sumy state university. Azerbaijan Medical Journal, 2016;2: 95-101.

26. Demikhova, N., Sukhonos, V., Vynnychenko, L. et al. Activation of lipid peroxidationin patients withrenal hypertension. Georgian Medical News, 2013; 215: 51-55.

27. Chernatska, O., Demikhova, N., Rudenko, T. et al. Assessment of the lipid profile correction in patients with arterial hypertension and type 2 diabetes mellitus. Azerbaijan Medical Journal,2019;1: 95-99.

28. Cherkashyna, L., Shklyar, A., Demikhova N. et al. Lipofuscin content in the muscle tissueduring the early postmortem period: improvement of forensic diagnosis of the prescription of death coming. Pol Merkur Lekarski, 2020;48(284): 35-39.

29. Bashynska, I., Kovalova, O., Malovichko, O. et al. Risk Management of Innovative Socially Significant Projects.International Journal of Advanced Research in Engineering and Technology,2020;11(4): 294-305.

30. Cherkashyna, L., Reminetskyy, B., Miz, A. et al. The content of lactate in muscle tissue of different types in the early post-mortal period. Pol Merkur Lekarski, 2020;48(287): 21-27.

31. Prokopenko, O., Holmberg, R., Omelyanenko, V. et al. Information and communication technologies support for the participation of universities in innovation networks (comparative study). Innovative Marketing,2018;14(3): 17-29. 